\title{
Analysis of Squash (Cucurbitaceae) Production in North- Western Benin: Case Study of Djougou and Bassila
}

\section{Communes}

\section{Dossa $\mathrm{KF}^{*}$ and Miassi ESY \\ Department of Rural Economics and Sociology, Faculty of Agronomy, University of Parakou, BP 123, Parakou, Benin}

*Corresponding author: Dossa Fabrice K, Department of Rural Economics and Sociology, Faculty of Agronomy, University of Parakou, BP 123, Parakou, Benin, Tel: 00229-96-78-97-32; E-mail: fabdossa@gmail.com

\section{Abstract}

Squash is one of the oldest crops produced in rural households in Africa as in Benin. It is a potential source of energy in the diet evidenced by its content of protein and lipids. The study aims to analyze the production of squash in the northwest of Benin. A total of 60 farmers were surveyed in two communes : Djougou and Bassila. The snowball sampling helped to establish the group of surveyed subjects. The data collected through semi-structured interviews were analyzed using statistical tools of SPSS v21 software. It appears from anlayzes that three (03) varieties of squash are produced in the north-west of Benin. Each of these varieties has special characteristics that influence the preferences of farmers about the cultivation of one or the other varieties. These assessments also define the market selling price. Out of the three (03) cultivated squash varieties, Lagenaria sicerania is the most widely grown in the study area, followed by Citrullus lanatus and Cucumeropsis edulis. The same trend is observed both for women and men. The analyzes revealed also that the variety Citrullus lanatus has not only the shortest cycle of production but also the highest yield. The yield of Citrullus lanatus varies between 1-1.2 tonnes/ha. Squash has different agronomic characteristics depending on the varieties grown. There is a great similarity between these varieties, however, some aspects like the shape of the pericarp, fruit color, resistance or not to insects attack help to distinguish varieties. As for the technical itinerary of production, it varies according varieties cultivated. Some varieties require more maintenance than others. Squash is used for various purposes in the study area. The main uses are selling, food, therapeutic treatments, traditional ceremonies and combustion. However, this crop is facing by certain constraints. The most important of those are financial, organizational, added by the lack of access to credit and lack of laborer. To face the numerous constraints, farmers proposed a series of actions that can help to develop this sector.

Keywords: Egoussi; Uses; Constraints; Selling Systems; Benin 


\section{Open Access Journal of Agricultural Research}

\section{Introduction}

Agriculture is the main income generating activity for rural people in Benin in general and in Northern Benin in particular. According to [1], the agricultural sector essentially ensures food security and constitutes the mean of subsistence of farmers, with $70 \%$ of the population who gets their income from agriculture. Dominated by cotton and maize, agricultural production still remains very diversified with a wide variety of crops grown [2]. Besides the main crops of farms, minor crops are associated in production systems in order to diversify sources of income. In this context, the squash commonly known as 'Egoussi' are among the oldest crops grown in small area in Benin to address the urgent economic needs as well as household food needs [3]. Squash seeds are a source of protein, fat and energy in the diet of West African countries such as Nigeria, Niger, Benin, Togo, Ghana and Ivory Coast. In Benin, despite the great variability of species and varieties of existing squash, only three species are the most grown because of their high content of protein and fat: Citrullus lanatus, Cucumeropsis edulis, Lagenaria siceraria $[3,4]$. The levels of protein and fat vary according to species but remain comparable to peanuts. For example, $\mathrm{C}$. lanatus contains 40 to $44 \%$ of fat, C. edulis 44 to $45 \%$ and L. siceraria 40 to $46 \%$ [5-7]. Given these advantages, one can agree that even if the squash is not part of the priority crops of the Strategic Plan for Agricultural Sector Recovery in Benin, it plays an important role in socio-economic and food situations of Beninese population. But despite all this contribution to food security and diversification of sources of income for farmers, it is noticed that this crop does not receive any special attention from Beninese agricultural research and policies. According to, Egoussi has long been absent from the main programs of research and development [8]. This seems paradoxical, especially in the current context where food security is a major concern for agricultural policies [9]. This study was conducted to promote a better understanding of 'Egoussi 'cultivation and improve poor literature on this crop. It aims to analyze the production of egoussi through different aspects. It consisted on one hand of exposing the varieties of squash grown, its technical itinaries and physical characteristics. On the other hand, we had to show up the uses made of squash seeds and its selling systems and then identify production constraints and the expectations of the farmers of 'Egoussi' in North western Benin.

\section{Materials and Methods}

\section{Study area}

This study was conducted in Northern Benin especially in the communes of Djougou and Bassila. These municipalities are located in the northwest of Benin and belongs to Donga. Djougou commune covers an area of $3,966 \mathrm{~km}^{2}$ and is one of four municipalities that make up the department of Donga in northern Benin. It is bounded to the north by the communes of Kouandé and Péhunco, south by the commune of Bassila, to the east by the communes of Sinendé, N'dali and Tchaourou and west by the communes of Ouaké and Copargo. Djougou capital of the town and the department, is located about $450 \mathrm{~km}$ from Cotonou. The commune of Bassila mean while extends over an area of 5,661 $\mathrm{km}^{2}$. It is bounded to the north by the communes of Ouaké and Djougou, to the south by the communes of Bantè, Glazoué, to the east by the communes of Tchaourou and Ouèssè and to the west by the Republic of Togo. Bassila, capital of the municipality, is located about $375 \mathrm{~km}$ from Cotonou (Benin's economic capital city) and $87 \mathrm{~km}$ from Djougou (capital city of the department). Due their geographical situation, the two communes have a Sudano-Guinean climate, with a rainy season (from April to October) and a dry season (from October to April). The annual average precipitation is between 1200 and $1300 \mathrm{~mm}$. With this average, these towns are among those of highest rainfall in Benin. In the early rainy season, the area periodically knows the hurricanes blowing from east to west. At Djougou, soils are sandy-clay or laterite (gravelly or rocky) generally favorable to agriculture. At Bassila by cons, the soils are mainly consistitued of ancient crystalline formations with granite-gneiss rock favorable for crops but demanding water and good drainage. Regarding the vegetation, it is dominated by shrub and tree savannah in the two municipalities. Nearly $2,437 \mathrm{~km}^{2}$ of the area of Bassila and 37,182ha of the area of Djougou are occupied by classified forests under management.

\section{Sampling}

In this study, observation units are squash farmers. The investigations were conducted in four villages at two villages per commune. These are Frignon and Diepani in the commune of Bassila and then Donwari and Abitanga in the commune of Djougou. These villages were selected for two reasons: First, there are a large number of farmers in each municipality. 


\section{Open Access Journal of Agricultural Research}

In addition, agricultural agents and some farmers indicated during the exploratory survey that these villages were recording the most important Egoussi production in the study area. Only a total of 60 farmers was investigated due to temporal and financial constraints. The sample of the study was obtained through the snowball method. The choice of this method is justified by the lack of an organization of this sector. Indeed, this sector has neither a list of farmers or groups. Thus, the sample size was changing as long as new information was available.

\section{Collected Data and Data Collection}

Data collection of this study was mainly inspired by collection process of Dossa F, et al. [9]. Data were collected through individual and group interviews based on questionnaires and interview guides. A mixed collection approach was used to collect the data. Given that the data sought were both quantitative and qualitative, this study combined the individual interviews and focus groups to achieve the goals. The interviews concerned mainly quantitative data. Group interviews by cons served to collect qualitative data. The collected information are related to socioeconomic and demographic characteristics of farmers, production volume, acreage, sales prices, production constraints and expectations of farmers. Note that an exploratory survey was conducted to ensure that indexed communes were actually involved in the production of 'egoussi'.

\section{Data Analysis}

Quantitative data collected using questionnaires were inserted into SPSS v20 32bit software for analysis. Therefore, averages, frequencies, minimum, maximum and standard deviations calculations have been used to present socio-demographic characteristics of farmers. Tests $t$ of Student and chi-square Pearson established links between the various parameters concerning the production of egoussi. The qualitative data were analyzed through discourse analysis. It consisted to assess the statements of farmers regarding the benefits and constraints of the production of 'egoussi'.

\section{Results and Discussion}

\section{Socioeconomic and Demographic Characteristics of Surveyed Farmers}

\begin{tabular}{|c|c|c|c|c|c|c|c|}
\hline \multirow{2}{*}{\multicolumn{2}{|c|}{ Quantitatives Variables }} & \multicolumn{2}{|c|}{ Djougou } & \multicolumn{2}{|c|}{ Bassila } & \multicolumn{2}{|c|}{ Together } \\
\hline & & Average & $\begin{array}{l}\text { Standard- } \\
\text { Deviation }\end{array}$ & Average & Ecart-type & Average & $\begin{array}{l}\text { Standard- } \\
\text { Deviation }\end{array}$ \\
\hline \multicolumn{2}{|c|}{ Age (years) } & 38.6 & 9.62 & 37.07 & 8.67 & 37.83 & 8.93 \\
\hline \multicolumn{2}{|c|}{ Farm assets } & 9.25 & 5.83 & 7.08 & 3.63 & 8.18 & 4.98 \\
\hline \multicolumn{2}{|c|}{$\begin{array}{c}\text { Distance between farms and } \\
\text { houses }(\mathrm{km})\end{array}$} & 0.03 & 0.07 & 0.28 & 0.12 & 0.15 & 1.03 \\
\hline \multicolumn{2}{|c|}{$\begin{array}{l}\text { Expérience in the production of } \\
\text { Egoussi }\end{array}$} & 26.72 & 7.48 & 22.4 & 4.66 & 24.56 & 5.83 \\
\hline \multirow{2}{*}{\multicolumn{2}{|c|}{ Qualitatives Variables }} & \multicolumn{2}{|c|}{ Djougou } & \multicolumn{2}{|c|}{ Bassila } & \multicolumn{2}{|c|}{ Together } \\
\hline & & $\begin{array}{l}\text { Absolute } \\
\text { frequency }\end{array}$ & $\begin{array}{c}\text { Relative } \\
\text { frequency }\end{array}$ & $\begin{array}{l}\text { Absolute } \\
\text { frequency }\end{array}$ & $\begin{array}{c}\text { Relative } \\
\text { frequency }\end{array}$ & $\begin{array}{l}\text { Absolute } \\
\text { frequency }\end{array}$ & $\begin{array}{l}\text { Relative } \\
\text { frequency }\end{array}$ \\
\hline \multirow{2}{*}{ Gender } & Men & 23 & 76.66 & 21 & 70 & 44 & 73.3 \\
\hline & Women & 7 & 23.34 & 9 & 30 & 16 & 26.7 \\
\hline \multicolumn{2}{|c|}{ Access to crédit } & 2 & 6.67 & 1 & 3.34 & 3 & 5 \\
\hline \multirow{3}{*}{$\begin{array}{l}\text { Prosperty } \\
\text { level }\end{array}$} & Very poor & 25 & 83.33 & 18 & 60 & 43 & 71.7 \\
\hline & Poor & 5 & 16.67 & 6 & 20 & 11 & 18.3 \\
\hline & Rich & 0 & 0 & 6 & 20 & 6 & 10 \\
\hline \multirow{3}{*}{$\begin{array}{l}\text { Level of } \\
\text { education }\end{array}$} & No & 23 & 76.66 & 27 & 90 & 50 & 83.3 \\
\hline & Primary & 5 & 16.67 & 2 & 6.67 & 7 & 11.7 \\
\hline & Secondary & 2 & 6.67 & 1 & 3.33 & 3 & 5 \\
\hline \multirow{3}{*}{$\begin{array}{l}\text { Principal } \\
\text { activity }\end{array}$} & Agriculture & 26 & 86.66 & 22 & 73.34 & 48 & 80 \\
\hline & Breeding & 1 & 3.34 & 4 & 13.33 & 4 & 6.7 \\
\hline & Trade & 3 & 10 & 4 & 13.33 & 8 & 13.3 \\
\hline Secondary & Agriculture & 3 & 10 & 7 & 23.33 & 10 & 16.7 \\
\hline
\end{tabular}




\section{Open Access Journal of Agricultural Research}

\begin{tabular}{|c|c|c|c|c|c|c|c|}
\hline activity & Breeding & 6 & 20 & 6 & 20 & 12 & 20 \\
\cline { 2 - 8 } & Trade & 21 & 70 & 17 & 56.67 & 38 & 63.3 \\
\hline \multirow{4}{*}{$\begin{array}{c}\text { Main ethnic } \\
\text { groups }\end{array}$} & Nago & 9 & 30 & 1 & 3.33 & 10 & 13.3 \\
\cline { 2 - 8 } & Lokpa & 6 & 20 & 9 & 30 & 15 & 20 \\
\cline { 2 - 8 } & Bariba & 3 & 10 & 3 & 10 & 6 & 6.7 \\
\cline { 2 - 8 } & Dendi & 6 & 20 & 9 & 30 & 15 & 36.7 \\
\cline { 2 - 8 } & Others & 6 & 20 & 8 & 26.67 & 14 & 23.3 \\
\hline
\end{tabular}

Source : Survey results(2018).

Table 1: Socioeconomic and demographic characteristics of farmers.

The results in Table 1 indicate that farmers are relatively old. With an average age of 38 years, the age of farmers varies between 29 and 46 years. The study area is characterized by a variety of ethnic groups. Overall, the dominant ethnicity is Dendi (36.7\%). By cons, even if it is true that Dendiis the dominant ethnic group in the commune of Bassila, that is not the case in the town of Djougou which dominant ethnic group is Nago. The results in Table 1 also indicate that men (73.3\%) engage more in agricultural activities than women $(26.7 \%)$ due to their role as head of household and the access to land is also facilitated for them. Given agriculture is the main activity $(80 \%)$ of survey units, the experience of the farmers in this area is on average at 24.5 years, with an average of 08 years per agricultural household assets constituting the majority of the work force of households. Trade is the secondary activity most practiced by the respondents. $63.3 \%$ of squash farmers are engaged in this activity. Then come as secondary activities practiced breeding (20\%) and agriculture (16.7\%). As for education level, only $16.7 \%$ of the surveyed farmers received a formal education corresponding mostly to a primary level $(11.7 \%)$. The low level of farmers education is added to the difficult of access to credit (5\%) and constitute then constraints for the good management of agricultural production in the study area. These difficulties probably would be part of the causes of the low level of prosperity of the surveyed farmers. Nearly $71.7 \%$ of the surveyed farmers are very poor. By cons, the distance between farms and households is relatively low $(0.15 \mathrm{~km})$ faciliting the permanent presence of farmers in their farms.

\section{Varieties of Squash Cultivated in the Northwest of Benin and Local Names in Ethnic Lines}

Table 2 presents the scientific names of the cultivated squash varieties and the local names in the study area. It appears from this table that mainly three (03) varieties of squash are grown in the study area: the Citrullus lanatus, Lagenaria siceraria and the Cucumeropsis edulis. These varieties have different names from one ethnic group to another. However, the well known and most widespread name in the northwest of Benin is the egoussi, which comes from Nago language. The term 'Egoussi' is recognized by all ethnic groups as representing squash. However, one can easily see that specific local names are given to certain varieties depending on the ethnicity of the farmers.

\begin{tabular}{|c|c|c|}
\hline Ethnic groups & $\begin{array}{l}\text { Local names of } \\
\text { the varieties }\end{array}$ & Scientific names \\
\hline \multirow{3}{*}{ Lokpa } & Kakadaossi & Citrullus lanatus \\
\hline & Eschrikaka & Lagenaria siceraria \\
\hline & Guissi & Cucumeropsis edulis \\
\hline \multirow{3}{*}{ Bariba } & Egoussi & Citrullus lanatus \\
\hline & \multirow{2}{*}{$\begin{array}{c}\text { Amerikakan- } \\
\text { agoussi }\end{array}$} & Lagenaria siceraria \\
\hline & & Cucumeropsis edulis \\
\hline \multirow{3}{*}{ Nago } & \multirow{3}{*}{$\begin{array}{l}\text { Egoussi/ } \\
\text { agoussim }\end{array}$} & Citrullus lanatus \\
\hline & & Lagenaria siceraria \\
\hline & & Cucumeropsis edulis \\
\hline \multirow{3}{*}{$\begin{array}{c}\text { Autres (Anii, } \\
\text { Idatcha, Dendi, } \\
\text { Yom, Fons) }\end{array}$} & \multirow{3}{*}{$\begin{array}{c}\text { Kaka, } \\
\text { Koutchrotchro, } \\
\text { Egoussi, } \\
\text { Kakadaossi, } \\
\text { Eschrikaka, } \\
\text { Goussi }\end{array}$} & Citrullus lanatus \\
\hline & & Lagenaria siceraria \\
\hline & & Cucumeropsis edulis \\
\hline
\end{tabular}

Source : Survey results (2018)

Table 2: Varieties of cultivated squash and local names by ethnic groups.

\section{Distribution of Squash Varieties Grown by Gender}

Out of the three (03) cultivated squash varieties, Lagenaria sicerania is the most widely grown in the study area (Figure 1). About $87 \%$ of farmers cultivate this variety. Then come Citrullus lanatus $(11,67 \%)$ and Cucumeropsis edulis $(1,66 \%)$. The same trend is observed both for women and men. However, men grow longer Lagenaria sicerania (88.64\%) than women (81\%). Figure 1 shows the distribution of squash varieties grown by gender. 


\section{Open Access Journal of Agricultural Research}

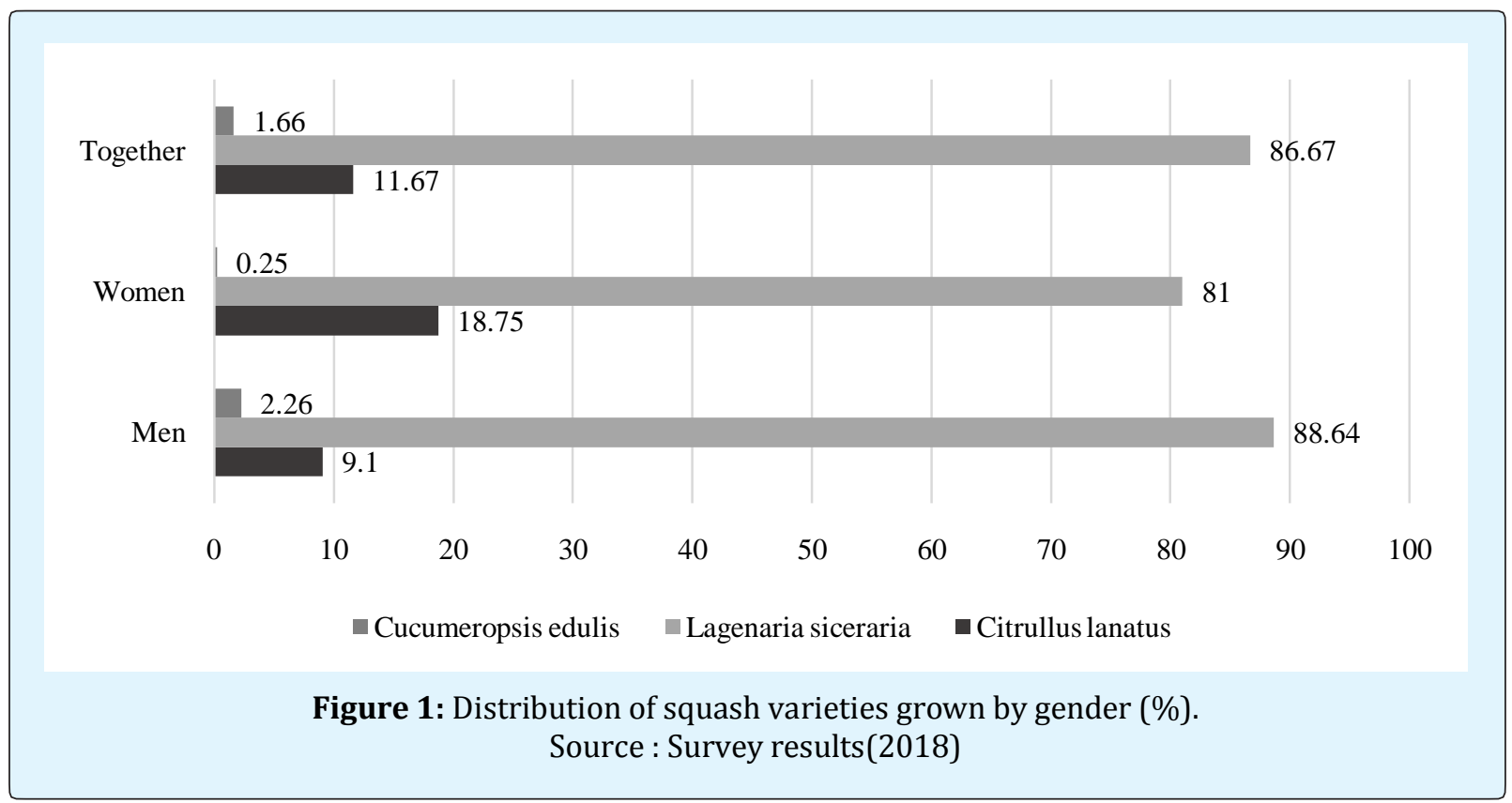

\section{Technical Itineraries of Squash Cultivation and Plant Characteristics}

Table 3 presents the technical itineraries of different varieties of squash grown in the study area. The results reported in this table reveals that the variety Citrullus lanatus's production cycle is the shortest. Moreover, this variety has the highest yield. The yield of Citrullus lanatus varies between 1-1.2 tonnes/ha. Analysis of the table also shows that squash has different agronomic characteristics depending on the varieties grown. There is a great similarity between these varieties, however, some aspects like the shape of the pericarp, fruit color, resistance or not to insects help to distinguish varieties. These results agree with those obtained by Achigan DGE, et al. [10,11]. As for the technical itinerary of production, it varies according varieties cultivated. Some varieties require more maintenance than others. This justifies the compulsory contribution of fertilizer for the production of Lagenaria siceraria.

\begin{tabular}{|c|c|c|c|c|}
\hline Cultivated varieties & $\begin{array}{c}\text { Production } \\
\text { cycles (month) }\end{array}$ & $\begin{array}{c}\text { Yield per ha } \\
\text { (tonnes) }\end{array}$ & $\begin{array}{c}\text { Physical characteristics of the } \\
\text { plant }\end{array}$ & $\begin{array}{c}\text { Technical itineraries of } \\
\text { production }\end{array}$ \\
\hline Citrullus lanatus & $2.5-3$ & $1-1.2$ & $\begin{array}{c}\text { Creeping, large roundpericarp } \\
\text { and not rigid, brown color with } \\
\text { black bord, easiest to shell }\end{array}$ & $\begin{array}{c}\text { Clearing-making balks- } \\
\text { seeding-weeding-harvest }\end{array}$ \\
\hline Lagenaria siceraria & $5-\mathrm{Apr}$ & 1 & $\begin{array}{c}\text { Creeping, little bitter, elongated } \\
\text { and very rigid pericarp, brown } \\
\text { fruit color, white flowers, most } \\
\text { attacked by insects, easy to shell }\end{array}$ & $\begin{array}{c}\text { Clearing-fertilization-making } \\
\text { balks-seeding-weeding- } \\
\text { harvest }\end{array}$ \\
\hline Cucumeropsis edulis & 10-Aug & 0.8 & $\begin{array}{c}\text { Climbing, sweet crude, little rigid } \\
\text { pericarp, white seeds color, } \\
\text { yellow flowers, hard to shell }\end{array}$ & $\begin{array}{c}\text { Clearing-seeding-weeding- } \\
\text { harvest }\end{array}$ \\
\hline
\end{tabular}

Source : Survey results(2018)

Table 3: Technical itineraries and physical characteristics of the cultivated squash varieties. 


\section{Open Access Journal of Agricultural Research}

\section{Selling Systems of Squash in Northwest of Benin}

Table 4 shows the prices and the appreciation of the quality of squash varieties grown in the study area. The table shows that the farmers have various appreciations of cultivated squash varieties. And that assessment counts for a lot in defining the basin selling price. Cucumeropsis edulis is the most expensive because this variety is very appreciated by farmers and local markets. The most important aspects of this variety that appreciate farmers are its ability to be stored for a long time, its organoleptic qualities and the fact that it does not require the application of fertilizers. Followed to the most expensive variety on the market, we have Citrullus lanatus (7500 FCFA/bowl) and Lagenaria siceraria (5000 FCFA/bowl) respectively due to the great resistance to disease and rot and the short cycle for one and weak demand in terms of maintenance for each others.

\begin{tabular}{|c|c|c|c|}
\hline Cultivated varieties & $\begin{array}{c}\text { Price of the basin } \\
\text { (Fcfa) }\end{array}$ & $\begin{array}{c}\text { Appreciation of the } \\
\text { quality }\end{array}$ & $\begin{array}{c}\text { Words/expressions used to appreciate the } \\
\text { quality }\end{array}$ \\
\hline Citrullus lanatus & 7500 & Good & Diseases and rots resistant, short cycle \\
\hline Lagenaria siceraria & 5000 & Poor & $\begin{array}{c}\text { Cycle not too long, requireslittle maintenance or } \\
\text { weeding }\end{array}$ \\
\hline Cucumeropsis edulis & $8500-10000$ & Very good & $\begin{array}{c}\text { Good organoleptic quality, doesn't require } \\
\text { fertilizers, occupieslittle spaces, easy to conserve }\end{array}$ \\
\hline
\end{tabular}

Source : Survey results(2018)

Table 4: Selling price and assessment of squash varieties qualities.

Table 5 in turn reveals that there are two sources of squash seeds: The local market and the old harvest. From both sources of seed supply, the most used by respondents farmers in the northwest of Benin is the use of old haverst. $78 \%$ of respondents prefer to sow the remains of harvested products of previous seasons. The preference for this supply is linked to the farmers' appreciation of yield and germination of seeds. According to farmers, seeds from former harvests have the highest performance and germination power.

\begin{tabular}{|c|c|c|}
\hline Sources of supply & $\begin{array}{c}\text { Distribution of respondents following the } \\
\text { source of supply }\end{array}$ & $\begin{array}{c}\text { Appreciation of germination power and } \\
\text { yield }\end{array}$ \\
\hline Local market & $28 \%$ & Medium \\
\hline Old harvest & $72 \%$ & High \\
\hline
\end{tabular}

Source : Survey results (2018)

Table 5: Sources of supply of squash seeds.

\section{Commercialization Process of Squash in the Northwest of Benin}

Table 6 expose the different marketing channels of squash. It appears that three selling chains are borrowed by farmers for their products.

(1) Farmers-Local market (retailer)

This is the shortest circuit to sell cultivated squash in the study area. This circuit is used by most farmers. $71.67 \%$ of the surveyed farmers sell directly harvested products to the nearest local market. However, this channe is more used at Bassila than Djougou to sell squash $(84.9 \%$ in Bassila against $58.44 \%$ in Djougou).

(2) Farmers-Urban collector
This is one of the less used channel in the study area. Overall, only $13.33 \%$ of the surveyed farmers sell their products directly to urban collectors. It is much more developed in Djougou because this town is the capital of the department and closer to major cities like Parakou and Cotonou.

(3) Farmers-Rural collector - Urban collector producer

This is the longest channel in the marketing of squash for all famers. But it is the second most used marketing channel by the farmers. About $25 \%$ of squash farmers sell their harvest products through this channel, even if it is much used by Djougou (12.46\%) than Bassila (0.9\%). 


\section{Open Access Journal of Agricultural Research}

\begin{tabular}{|c|c|c|c|}
\hline \multirow{2}{*}{ Marketing channels } & \multicolumn{3}{|c|}{ Distribution of respondents following squash marketing channels } \\
\cline { 2 - 4 } & Djougou (\%) & Bassila (\%) & Ensemble (\%) \\
\hline Farmers - Local market (retailer) & 58,44 & 84,9 & 71,67 \\
\hline Farmers - Urban collector & 29,02 & 14,2 & 13,33 \\
\hline $\begin{array}{c}\text { Farmer - Rural collector- Urban } \\
\text { collector }\end{array}$ & 12,46 & 0,9 & 25 \\
\hline
\end{tabular}

Source : Survey results (2018)

Table 6: Distribution of respondents following squash marketing channels.

Figure 2 shows schematically squash marketing channels and the relationships between actors within the study area. One can easily see that the relations between farmers and local retailers are the most privileged. This is due to the fact that farmers prefer to interact with actors in their entourages. Those are usually neighbors, friends, family members who sell in local markets. Farmers therefore prefer to sell products within the family circle. In this same circle, rural collectors are more privileged compared to urban collectors. Figure 2 also reveals that there is amedium relationship between rural collectors and farmers. By cons, the relationship between farmers and urban collectors is not very good. The first reason given by the farmers is the selling price. Urban collectors buy a large amount of squash and they also set the selling price which often is not suitable for farmers. In the marketing chain, rural collectors convey the collected products to urban collectors through carriers.

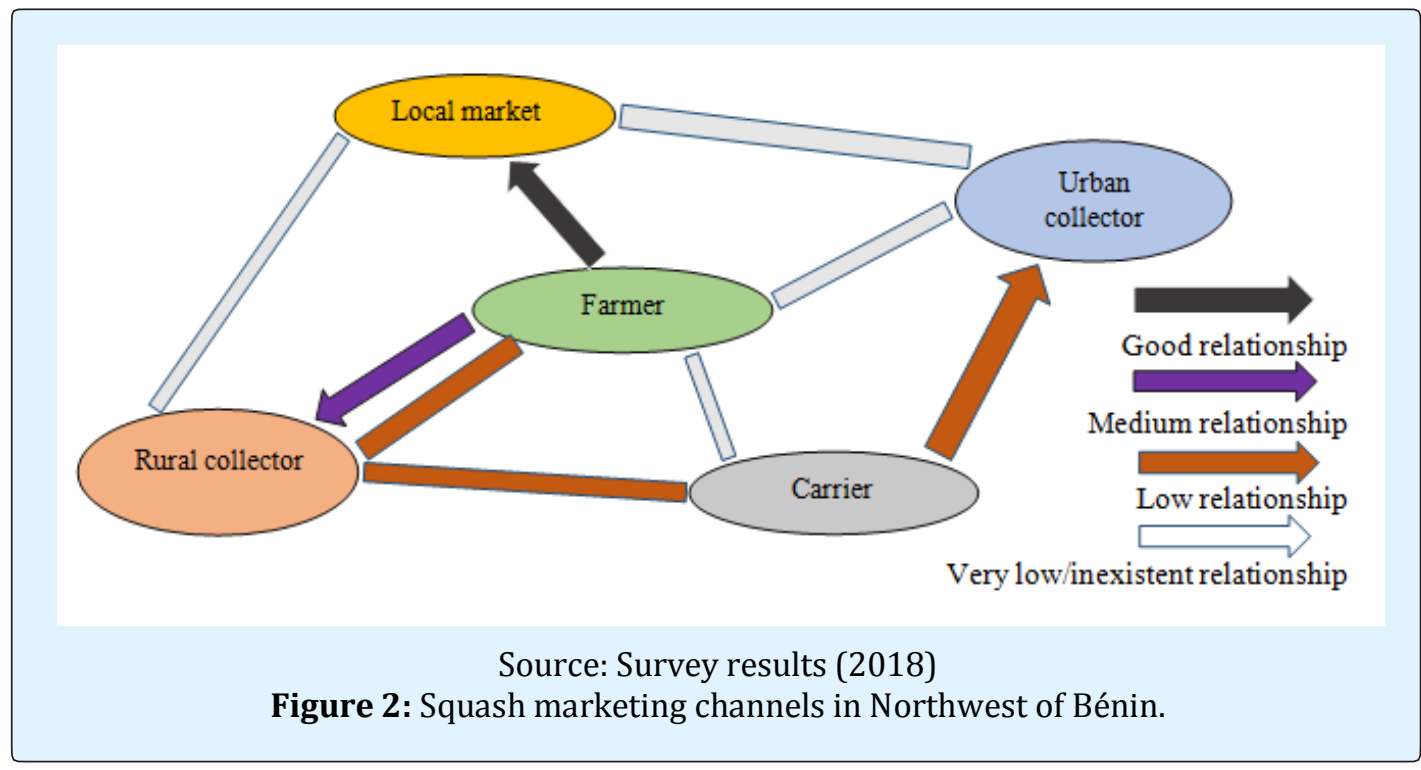

\section{Areas and Various uses of Harvested Squash in Northwest of Benin}

In general, farmers have an average cultivated area of five (05) hectares (Table7). The cultivated area is approximately the same in both investigated municipalities. However, it should be noted that squash production is still very low in the two municipalities, witness the area occupied by the production of squash in the study area. The 'egoussi' occupies only $1 / 5$ of the total cropping areas. Furthermore, the average of squash cultivated area in Djougou (1.5 ha) is slightly higher than
Bassila (1.06 ha). Table 7 shows the total cultivated area and the squash cultivated area.

\begin{tabular}{|c|c|c|c|}
\hline \multirow{2}{*}{ Variables } & \multirow{2}{*}{ Together } & \multicolumn{2}{|c|}{ Communes } \\
\cline { 3 - 4 } & & Djougou & Bassila \\
\hline Cultivated area (ha) & 4,94 & 5,55 & 4,33 \\
\hline Grown squash area (ha) & 0,78 & 1,06 & 0,50 \\
\hline
\end{tabular}

Source: Survey results (2018).

Table 7: Average cultivated area and squash spatial occupation. 


\section{Open Access Journal of Agricultural Research}

Table 8 by cons give informations on the various uses made of the 'egoussi' in the northwest of Benin. The results in the table indicate that there are five (05) large uses of squash. These are sale, medecine, food (sauce, doughnut, almond, powder, cheese), the realization of traditional ceremony and use as combustible (pericarp and tegument). Note however that despite this range of uses made, harvested squash are usually sold (55\%). Followed in order of importance the diet as a sauce, almond doughnut, powder or cheese (21\%); consumption for its therapeutic properties (18.3\%); use in the kitchen of the pericarp as combustible $(3.3 \%)$ and the use in traditional ceremonies (riding and burial of someone close). Some farmers affirm that the pericarp is also used as a musical instrument or recipient (calabash) when that is rigid. A comparison by gender shows that men produce squash primarily for sale, therapeutic treatments and ceremonies. On the other hand, women grow squashmainly for sale, feed and combustible. In rural areas, women are confined in a nurturing role. Thus women cook most of the times justifying the fact that they are the only ones who use the squash shells as combustible. When considering the use made following communes, we note that the sale, feed, and therapeutic treatments are the main uses made in Djougou and Bassila communes.

\begin{tabular}{|c|c|c|c|c|c|c|}
\hline \multicolumn{2}{|c|}{ Uses } & Number of farmers & \multicolumn{4}{|c|}{ Fréquences relatives (\%) } \\
\hline \multicolumn{2}{|c|}{ Sale } & 33 & \multicolumn{4}{|c|}{55} \\
\hline \multicolumn{2}{|c|}{ Medecine } & 11 & \multicolumn{4}{|c|}{18.3} \\
\hline \multicolumn{2}{|c|}{ Feed } & 13 & \multicolumn{4}{|c|}{21.7} \\
\hline \multicolumn{2}{|c|}{ Ceremonies } & 1 & \multicolumn{4}{|c|}{1.7} \\
\hline \multirow{2}{*}{\multicolumn{2}{|c|}{$\begin{array}{c}\text { Combustibles } \\
\text { Variables }\end{array}$}} & 2 & \multicolumn{4}{|c|}{3.3} \\
\hline & & Sale & Medecine & Feed & Ceremonies & Combustibles \\
\hline \multirow{2}{*}{ Gender (\%) } & Men & 56.81 & 22.73 & 13.64 & 6.81 & 0 \\
\hline & Women & 50 & 2.27 & 43.75 & 0 & 3.98 \\
\hline \multirow{2}{*}{ Commune(\%) } & Djougou & 60 & 10 & 23.33 & 3.33 & 3.33 \\
\hline & Bassila & 50 & 13.33 & 33.33 & 3.33 & 0 \\
\hline
\end{tabular}

Source : Survey results (2018)

Table 8: Various uses made of cultivated squash.

\section{Squash Production Constraints in Northwest of Benin}

Table 9 shows the constraints related to the production of squash and their distribution following gender and municipalities. From this table, it appears that several constraints undermine the production of squash in the northwest of Benin. These are: Lack of funding, lack of labor, insect attack, market access, lack of organization and supervision. Overall, these constraints are very important for farmers. However, those that farmers complain the most and require immediate action are lack of funding, market access and the lack of organization.
Given the production of squash is not a great sector, it does not receive any attention from agricultural development policies and structures. It is not organized as priority sectors. Farmers often fail to take out loans to start production on larger areas. In addition, as announced earlier farmers claim they are unable to sell their products after harvest. When customers come, they set selling prices themselves and usually the products are sold off in order not to consume all in the household. This same trend is observed when a comparison of these constraints is made following gender and municipalities.

\begin{tabular}{|c|c|c|c|c|c|}
\hline \multirow{2}{*}{ Constraints } & \multirow{2}{*}{ Together } & \multicolumn{2}{|c|}{ Gender } & \multicolumn{2}{c|}{ Communes } \\
\cline { 3 - 6 } & & Women & Men & Djougou & Bassila \\
\hline Lack of funding & 95 & 100 & 93.18 & 96.67 & 93.33 \\
\hline Lack of labor & 73.3 & 75 & 72.73 & 60 & 86.67 \\
\hline Insect attack & 60 & 56.25 & 61.36 & 46.67 & 73.33 \\
\hline market access & 90 & 14,28 & 90.9 & 83.33 & 96.67 \\
\hline lack of organization & 90 & 14.28 & 90.9 & 96.67 & 83.33 \\
\hline Lack of supervision & 58.3 & 56.25 & 59.1 & 46.67 & 70 \\
\hline
\end{tabular}

Source : Survey results (2018)

Table 9: Distribution of constraints related to the production of squash following gender and communes (in \%). 


\section{Open Access Journal of Agricultural Research}

\section{Expectations of Squash Farmers in Northwest of Benin}

Given the constraints farmers proposed a serie of actions to be taken to improve the production of squash in the study area. These actions in upstream or downstream will not only improve the living and production conditions of the farmers but also to ensure food security of the Beninese population. The proposed actions include:

1) Create microcredit institutions to grant loans to farmers. It could help the majority to fund their production.

2) Initiate opportunities, programs and projects to develop nutritional and agronomic characteistics of this culture.

3) Having a framing service on good practices and techniques of squash production

4) Improving yield of seeds through agricultural research

5) Having specific inputs or possibly credit-inputs as in cotton production

6) Organizing the farmers in of Village Groups and Regional Unions

7) Integrating URCUMA (Regional Union of Agricultural Materials Users Cooperatives) to access to agricultural materials needed for sowing large areas.

8) Making available to the farmers, pesticides to face effectively insect attacks and parasites.

\section{Conclusion}

This study was conducted to analyze the production of squash in the northwest of Benin. In that area of Benin, three (03) varieties of squash are grown. Each of these varieties have specific characteristics that affect the choice of producers to cultivateone of them. These assessments also define the market selling price. Both advantageous than binding, squash is an important in feed as well as in socioeconomic situation of farmers. Squash is directly consumed by farmers sold or used as nutraceuticals in therapeutic treatments. Given the many constraints faced by farmers, they proposed a serie of actions in oder to develop this crop cultivation. Particular attention of agricultural policies should be given to these actions in order to revitalize this sector.

\section{References}

1. PNUD (2016) Rapport national sur le développement humain 2015: Agriculture, Sécurité Alimentaire et Développement Humain au Benin. pp: 141.

2. Dossa KF, Todota TC, Miassi YES (2018) Focusing on food security or targeting the economy: A study on cotton and maize production in Kandi commune. Open Acc J Envi Soi Sci 1(1): 1-6.

3. Salifou A, Alidou C, Tchobo FP, Soumanou MM (2015) Connaissances endogènes et importance des courges (Cucurbitacées) pour les populations autochtones productrices des graines au Bénin. Journal of Applied Biosciences 92: 8639-8650.

4. Vodouhè RS, Achigan-Dako GE, Dulloo ME, Adjakidje $V$ (2001) Observation de la diversité génétique des Egusi collectées au Bénin et au Togo. Acte 2 de l'Atelier Scientifique Sud et Centre, Niaouli, 12-13 décembre 2001. Institut National des Recherches Agricoles du Bénin. pp: 53-61.

5. Badifu GIO, Ogunsua AO (1991) Chemical composition of kernels from some species of cucurbitaceae grown in Nigéria. Plant Foods Hum Nutr 41(1): 35-44.

6. Norman JC (1992) Tropical vegetable crops. AH Stockwell 6(3): 107-119.

7. Schippers RR (2000) African Indigenous vegetables: an overview of the cultivated species. Natural Resources Institute/ACP-EU Technical Centre for Agricultural and Rural Cooperation pp: 221.

8. Williams JT, Haq N (2002) Global research on underutilized crops. An assessment of current activities and proposal for enhanced cooperation. ICUC pp: 46.

9. Dossa F, Miassi Y, Banzou K (2018) Onion (Allium Cepa) Production in Urban and Peri-Urban Areas: Financial Performance and Importance of This Activity for Market Gardeners in Southern Benin. Curr Investig Agric Curr Res Lupine Publishers 3(2): 1-13.

10. Achigan DGE (2002) Caractérisation morphologique et analyse du niveau de ploïdie des Cucurbitaceae du genre Lagenaria siceraria prospectées au Bénin et au Togo, Mémoire de DEA. UFR Biosciences, Université de Cocody, Côte d_Ivoire pp: 52 .

11. Achigan DGE, Fanou N, Kouke A, Avohou H, Vodouhè SR, et al. (2006) Évaluation agronomique de trois espèces de Egusi (Cucurbitaceae) utilisées dans l'alimentation au Bénin et élaboration d'un modèle de prédiction du rendement. Biotechnologie Agronomie Société Environnement 10(2): 121-129. 